DOI: $10.17516 / 1997-1370-0776$

УДК 338.45.01.001.76:330.35

\title{
Innovative Potential of Industry and Productive Power of Science as the Factors of Economic Growth
}

\author{
Lyudmila N. Perepechko*a and Miron A. Yagolnitser ${ }^{\mathrm{b}}$ \\ ${ }^{a}$ Kutateladze Institute of Thermophysics of the SB RAS \\ Novosibirsk, Russian Federation \\ ${ }^{b}$ Institute of Economics and Industrial Engineering of Siberian Branch \\ of the Russian Academy of Sciences \\ Novosibirsk, Russian Federation
}

Received 21.05.2021, received in revised form 15.06.2021, accepted 01.07.2021

\begin{abstract}
The relationship of indicators of intellectual property (IP) with indices characterizing the effectiveness of the national innovation system and the state of its subjects - science and industry - has been identified and justified based on the analysis of statistical data for 40 countries, selected by the share of high-tech products in the export. Two factors have been identified: the first factor is related to industry and can be called «innovative industrial potential». The second factor is related to GDP, protection of IP abroad, funding of science and IP revenues. It can be conditionally attributed to the productive power of science. The number of research personnel also correlates with these indicators. This study confirms the inextricable relationship between the indices of the innovative state of science and industry, whose characteristics include R\&D funding, export of high-tech products, IP, and production of metalworking equipment.
\end{abstract}

Keywords: intellectual property, patent statistics, commercialization of innovations, indicators of innovative development, statistical analysis.

The article was prepared within the framework of the state assignment for project 5.6.1.5. (0260-2021-0002) «Integration and interaction of mesoeconomic systems and markets in Russia and its eastern regions: methodology, analysis, forecasting».

Research area: economics.

Citation: Perepechko, L.N., Yagolnitser, M.A. (2021). Innovative potential of industry and productive power of science as the factors of economic growth. J. Sib. Fed. Univ. Humanit. Soc. Sci., 14(7), 966-977. DOI: $10.17516 / 1997-1370-0776$.

(C) Siberian Federal University. All rights reserved

* Corresponding author E-mail address: ludmila@itp.nsc.ru, miron@ieie.nsc.ru ORCID: 0000-0002-0613-2907 (Perepechko); 0000-0002-7661-053X (Yagolnitser) 


\title{
Инновационный потенциал промышленности и производительная сила науки как факторы экономического роста
}

\author{
Л.Н. Перепечко, М.А. Ягольницер ${ }^{6}$ \\ аинститут теплофизики им. С. С. Кутателадзе СО РАН \\ Российская Федерачия, Новосибирск \\ ${ }^{6}$ Институт экономики и организащии \\ промылиленного производства СО РАН \\ Российская Федерачия, Новосибирск
}

\begin{abstract}
Аннотация. На основе анализа статистических данных 40 стран, отобранных по доле в экспорте высокотехнологичной продукции, выявлена и обоснована связь показателей по интеллектуальной собственности (ИС) с индексами, характеризующими эффективность работы национальной инновационной системы и состояние ее субъектов - науки и промышленности. Выявлено два фактора: первый связан с промышленностью и может быть назван «инновационный промышленный потенциал»; второй связан с ВВП, защитой ИС за рубежом, финансированием науки и доходами от ИС. Его можно условно отнести к «производительной силе науки». С этими показателями коррелирует также численность исследовательского персонала. Данное исследование подтверждает неразрывную связь индексов инновационного состояния науки и промышленности, среди показателей которых финансирование НИОКР, экспорт высокотехнологичной продукции, ИС и производство металлообрабатывающего оборудования.
\end{abstract}

Ключевые слова: интеллектуальная собственность, патентная статистика, коммерциализация инноваций, измерители инновационного развития, статистический анализ.

Статья подготовлена в рамках государственного задания по проекту 5.6.1.5 (02602021-0002) «Интеграция и взаимодействие мезоэкономических систем и рынков в России и ее восточных регионах: методология, анализ, прогнозирование».

Научная специальность: 08.00.00 - экономические науки.

\section{Introduction}

Over the past half century, a key factor in the development of economic systems has been presented by innovations, which have determined the qualitative changes in interaction of science, business, and state. In the post-industrial economy, these main subjects of the national innovation system (NIS) - the state, science, and business - become closer and their functions intersect; and according to the triple helix model, representatives of science occupy a dominant position in the system of innovative development (Etzkowitz, 2008; Leydesdorff, 2005).
In innovative economy, science acquires the features of productive power; universities carry out applied research, create engineering centers and small innovative enterprises, and receive income from the transfer of knowledge and intellectual property rights to industry. Business creates scientific departments and finance research, receives income from the hightech productions.

Thus, accelerated commercialization of innovations takes place, and rapidly developing and highly profitable market of intellectual property (IP), production and export of high-tech 
products (hi-tech) are the results of this process. Accordingly, there should be a link between high-tech export performance and IP market.

Therefore, the successful commercialization of inventions and new technologies requires the close level of «innovative development» of industry and science.

Is it possible to measure the level of innovative development of industry and science?

\section{Systems for measuring the innovative development of industry and science}

Currently, in literature and economic theory there are a significant number of methods for assessing innovative development, primarily on the basis of global innovation indices (The Global Innovation Index, 2012) and intellectual property $^{1}$, but is it possible to distinguish the factors related to industry and science among them?

Intellectual property of the country (i. e., IP owned by the residents, individuals, and legal entities) is associated with all subjects of NIS and their state: the level of high-tech industry development, the level of human capital development, legislative and monetary policy of the country, funding of research and even with national characteristics of economy (Chulok, 2006; Acs, Audretsch, 1989; WIPO website, Global Innovation Index, 2012). Indices related to IP are included in all official statistical statements characterizing the level of economy, science, industry, and labor resources development.

The index associated with intellectual property, its types and dynamics is objective and accurate. Information on IP, patent applications and patents in each country, which is a member of the World Intellectual Property Organization (WIPO) is reliable, open, accessible, and uniform. A patent is an open document containing information about the authors, right holders, territory of protection, filing date, technical field of invention, its analogues, and application text.

The generally accepted clause in foreign sources is that patent statistics provides the measurement of innovative activities (Acs, Audretsch, 1989). The number of patents obtained almost directly depends on the volume of investments in $R \& D$ of industrial enterprises
(Griliches, 1990). Such dependence allows us to reasonably speak about a certain objective indicator of the technological level of a company or even a country, which correlates very well with $R \& D$ expenses and the number of patents owned by the company (state).

A comparison of patent indicators and indicators of $R \& D$ costs can serve as one of the indicators of the economic efficiency of the latter (Belousova, 2016).

An analysis based on the number of patents yields the results that coincide with other more or less direct dimensions of innovation (European Commission, 2007; European Commission, 2005) by the European Commission, which makes it possible to consider the growth rate of patents as an effective indicator of changes in innovative dominance. In addition, the use of data from WIPO, the European Patent Office and national patent offices for comparative analysis has become common practice both in political documents $[9,10]$ of the EU and in academic studies (Smith, 2004; Fagerberg, Feldman, Srholec, 2011).

The data on applications for inventions and the number of patents for inventions are most widely used in economic studies.

The number of patents is one of the components of «technological capital» (Fagerberg, Feldman, Srholec, 2011; Innovation: a EuropeUnited States...) and is used to compare technological capabilities and development of the USA and Europe: two world regions that have comparable political weight. To assess technological potential and innovation in general, it is proposed to use investments in R\&D and other indicators related to knowledge dissemination and use. Based on factor analysis, J. Fagerberg has substantiated the relationship of such indicators as the number of scientific papers, international patents, and business investment in $\mathrm{R} \& \mathrm{D}$, suggesting the presence of a certain factor, which he called «technological capital» (Fagerberg, Feldman, Srholec, 2011). At that, state investments in R\&D practically do not correlate with the above indicators.

The indicators of the effectiveness of IP commercialization are the rating ones for the universities (for example, the rating agency CWUR draws attention to the number of inter- 
national patent applications made on behalf of the university).

On the other hand, the total number of patents for inventions is an important indicator, but it cannot be the only measure of innovation (Smith, 2004). Patenting is used in some technological fields (chemistry, biotechnology) more widely than in others. Many inventors protect the inventions which will never enter the market with patents; on the other hand, many innovations that have entered the market are not patented. Therefore, although patents provide complete information on certain issues of technological activity, it is necessary to use other IP indicators to assess the level of economic development.

\section{Choice of indicators}

To justify the choice of IP indicators, we have analyzed the relationship between IP data and the stages of innovation commercialization. While inventions may appear in universities and research institutes, other objects of industrial property, such as trademarks and industrial designs, are protected primarily by industrial enterprises. The stages of innovation commercialization are related to the characteristics of the resulting IP and right holders in the following manner (Table 1): at the stage of fundamental and exploratory research, IP is protected in the form of know-how or invention, the right holder is a university (research institute);

in applied works, inventions are protected, the right holders are R\&D executors, industrial enterprises;

at the stage of export, inventions are also protected abroad.

Other objects of industrial property (industrial designs and trademarks) appear at mass production, and expansion of the territory of their protection indicates an access to the international markets.

Receipts from mass production and export are used to finance new R\&D: this is how the «flywheel of innovation» spins.

In addition, depending on the type of $\mathrm{R} \& \mathrm{D}$, the number of inventions related to one innovation is growing; with expansion of production, the number of trademarks (TM) and industrial designs is growing, and the cost of intellectual property items is increasing (a ProLicensing Era?).

This ratio of commercialization stages and IP characteristics allows using the IP structure as an indicator of the state of research at each stage, characteristic of the innovative level of NIS subjects, and intensity of their interaction (Table 1).

Table 1 . The scheme of a change in the structure and characteristics of intellectual property at various stages of commercialization of innovations in the post-industrial structure

\begin{tabular}{|c|c|c|c|c|c|c|}
\hline $\begin{array}{c}\text { Innovation } \\
\text { stage }\end{array}$ & $\begin{array}{c}\text { Research, } \\
\text { basic (orient- } \\
\text { ed) research }\end{array}$ & $\begin{array}{c}\text { Research, } \\
\text { applied } \\
\text { research }\end{array}$ & Development & Pilot batch & $\begin{array}{c}\text { Mass } \\
\text { production }\end{array}$ & Export \\
\hline Type of IP & $\begin{array}{c}\text { Know-how, } \\
\text { invention }\end{array}$ & Invention & Invention & Invention & $\begin{array}{c}\text { TM, indus- } \\
\text { trial designs }\end{array}$ & $\begin{array}{c}\text { Invention, } \\
\text { industrial } \\
\text { designs, TM }\end{array}$ \\
\hline $\begin{array}{c}\text { Territory of } \\
\text { protection }\end{array}$ & National & National & National & $\begin{array}{c}\text { National, } \\
\text { abroad }\end{array}$ & $\begin{array}{c}\text { National, } \\
\text { abroad }\end{array}$ & $\begin{array}{c}\text { National, } \\
\text { abroad }\end{array}$ \\
\hline $\begin{array}{c}\text { Right holders } \\
\text { Research in- } \\
\text { stitutes, uni- } \\
\text { versities, state }\end{array}$ & $\begin{array}{c}\text { Research } \\
\text { institutes, } \\
\text { universities, } \\
\text { business }\end{array}$ & Business & Business & Business & Business \\
\hline Funding & State & $\begin{array}{c}\text { State and } \\
\text { business }\end{array}$ & $\begin{array}{c}\text { Business } \\
\text { and state }\end{array}$ & Business & Business & Business \\
\hline
\end{tabular}

Compiled by the authors. 
Inventions are the basis for the creation of innovations, as well as creation of trademarks (TM) and industrial designs, accompanying the process of commercialization which characterizes intensity of this process. Significant material and human resources are required to create an invention, and TM and industrial designs practically do not bear the material or intellectual costs for their creation.

Therefore, inventions, trademarks and industrial designs can be a characteristic of the level of development of all NIS elements: science, industry, education, society (human capital), institutions, and infrastructure.

In addition to the IP data, it is possible to evaluate the innovative state of science by the number of researchers and funding by business.

How to evaluate the innovative state of industry? The main criterion for developed hightech industry is the export of products with a high share of added value.

As it was shown in (Perepechko, 2014; WIPO website), the production of metalworking equipment, or machine-tool construction is an important indicator of industrial and high-tech development. Occupying only a few percent of the share of manufactured goods, machine-tool construction is fundamental to the development of all industries. It provides the main production base, which includes production facilities, qualified personnel, and industrial culture (Heinrich, 2001). Machinetool industry determines the scientific and technological progress in the modern world, it is capital intensive, and requires the use of highly qualified labor resources; therefore it is localized mainly in industrially advanced countries. Machine-tool construction data are also reliable, as there are analytical reviews of machine-tool companies, for instance, Gardner Business Media, Inc. ${ }^{1}$ publishes annual reviews on machine-tool construction.

Therefore, to assess the innovative potential of industry, it is proposed to add an indicator related to production and export of metalworking equipment. Metalworking equipment (MWE) is one of the important components of high-tech export: its production, export and import can also characterize the innovative development of industry. According to Gardner
Business Media, Inc, any significant export of high-tech products, production of MWE and IP ownership are carried out by 3-4 dozen of countries. The same countries implement export and import of MWE.

The leaders in MWE production in 2015 were China, Japan, Germany and the USA. The remaining countries produce less than a half of the total MWE. In BRIC countries, MWE import prevails over its export. The indicators of MWE production and export can be a characteristic of the state of high-tech industry and can be related to the IP market. Further, this was confirmed by a strong correlation between the production of MWE, high-tech export, and IP data (Table 2).

Forty countries were selected to check the hypothesis concerning the relationship between innovative indicators of industry and science, and IP indices. They were selected according to one criterion: high-tech export. This criterion was chosen because it completes the process of commercialization and is a measure of innovation success.

If countries are ranked by the share in the export of high-tech manufacturing sector (high-tech), then it turns out that 40 first countries export almost 100 percent of the world high-tech products (Yagolnitser, Perepetchko, 2017; Chulok, 2006).

This number includes the same countries as the countries that produce, export, and import metalworking equipment and possess IP. Further, for these 40 countries, according to Appendix A, the pair correlation coefficients (Pearson) are calculated.

\section{Results}

The indicators used in this study, 13 in total:

GDP;

export of high-tech products; the number of resident applications for inventions to the National Patent Office (NPO); the number of resident applications for inventions filed abroad; the number of resident applications for industrial designs to NPO;

the number of resident applications for industrial designs filed abroad; 
the number of resident applications for TM to NPO;

the number of resident applications for TM filed abroad;

total funding of science;

funding of science by business; ment;

production of metalworking equip-

receipt from IP;

payments for IP.

The obtained correlation coefficients are presented in Table 2.
Then the factor analysis was performed, and two factors were identified. The first is related to industry and may be called «innovative industrial potential», the second is related to GDP, IP protection abroad, science funding and IP receipt. It can be conditionally attributed to scientific business: the productive power of science. Factor loads are given in Table 3.

Thus, the data on the IP objects can be indicators of the innovative level of industry: these are the data on inventions, TM, industrial designs of the National Patent Office (NPO),

Table 2. Correlation coefficients between indicators of innovative level of science and industry according to the data for $2016^{*}$

\begin{tabular}{|l|c|c|c|c|c|c|c|c|c|c|c|c|c|}
\hline & 1 & 2 & 3 & 4 & 5 & 6 & 7 & 8 & 9 & 10 & 11 & 12 & 13 \\
\hline Export of high-tech products & 1.00 & & & & & & & & & & & & \\
\hline $\begin{array}{l}\text { Applications for in- } \\
\text { ventions to NPO }\end{array}$ & $\mathbf{0 . 9 1}$ & 1.00 & & & & & & & & & & & \\
\hline $\begin{array}{l}\text { Applications for inven- } \\
\text { tions filed abroad }\end{array}$ & 0.46 & 0.40 & 1.00 & & & & & & & & & & \\
\hline Applications for TM to NPO & $\mathbf{0 . 8 7}$ & $\mathbf{0 . 9 7}$ & 0.17 & 1.00 & & & & & & & & & \\
\hline $\begin{array}{l}\text { Applications for TM } \\
\text { filed abroad }\end{array}$ & 0.57 & 0.39 & 0.66 & 0.30 & 1.00 & & & & & & & & \\
\hline $\begin{array}{l}\text { Applications for indus- } \\
\text { trial designs to NPO }\end{array}$ & $\mathbf{0 . 8 8}$ & $\mathbf{0 . 9 6}$ & 0.17 & $\mathbf{0 . 9 9}$ & 0.33 & 1.00 & & & & & & & \\
\hline $\begin{array}{l}\text { Applications for industri- } \\
\text { al designs filed abroad }\end{array}$ & 0.56 & 0.39 & 0.68 & 0.29 & $\mathbf{0 . 9 6}$ & 0.32 & 1.00 & & & & & & \\
\hline GDP & 0.66 & 0.67 & $\mathbf{0 . 7 9}$ & 0.54 & $\mathbf{0 . 7 1}$ & 0.50 & 0.66 & 1.00 & & & & & \\
\hline Science expenses & 0.61 & 0.60 & $\mathbf{0 . 8 6}$ & 0.44 & $\mathbf{0 . 7 1}$ & 0.41 & 0.67 & $\mathbf{0 . 9 8}$ & 1.00 & & & & \\
\hline MWE production & $\mathbf{0 . 8 6}$ & $\mathbf{0 . 8 5}$ & 0.59 & $\mathbf{0 . 7 6}$ & 0.58 & $\mathbf{0 . 8 0}$ & 0.62 & 0.60 & 0.57 & 1.00 & & & \\
\hline Science funding by business & 0.66 & 0.67 & $\mathbf{0 . 8 6}$ & 0.50 & 0.69 & 0.48 & 0.66 & $\mathbf{0 . 9 8}$ & $\mathbf{0 . 9 9}$ & 0.64 & 1.00 & & \\
\hline Payments for IP & 0.36 & 0.28 & 0.46 & 0.20 & 0.38 & 0.18 & 0.34 & 0.47 & 0.49 & 0.26 & 0.48 & 1.00 & \\
\hline Receipt from IP & 0.27 & 0.21 & $\mathbf{0 . 8 5}$ & 0.02 & 0.64 & 0.01 & 0.59 & $\mathbf{0 . 8 0}$ & $\mathbf{0 . 8 6}$ & 0.24 & $\mathbf{0 . 8 3}$ & 0.57 & 1.00 \\
\hline
\end{tabular}

Calculated by the authors based on data of the World Bank, WIPO, UNESCO and Gardner Business Media.

*Note: the following notations are accepted here:

1. - Export of high-tech products in US dollars;

2. - Number of applications for inventions to NPO, it.;

3. - Number of applications for inventions filed abroad, it.;

4. - Number of applications for TM to NPO, it.;

5. - Number of applications for TM filed abroad, it.;

6. - Number of applications for industrial designs to NPO;

7. - Number of applications for industrial designs filed abroad;

8. - GDP in US dollars;

9. - Science expenses - by all sources, in US dollars;

10. - Production of metalworking equipment (MWE) - in millions of US dollars, in 2015;

11. - Science funding by business in US dollars;

12. - Payments for IP - in US dollars;

13. - Receipt from IP - in US dollars. 
Lyudmila N. Perepechko and Miron A. Yagolnitser. Innovative Potential of Industry and Productive Power of Science...

Table 3. Results of factor analysis by 40 countries and 13 indicators

\begin{tabular}{|l|c|c|}
\hline & Factor 1 & Factor 2 \\
\hline Export of high-tech products & $\mathbf{0 . 8 7 7}$ & 0.378 \\
\hline Applications for inventions to NPO & 0.943 & 0.278 \\
\hline Applications for inventions filed abroad & 0.135 & $\mathbf{0 . 9 1 0}$ \\
\hline Applications for TM to NPO & 0.979 & 0.087 \\
\hline Applications for TM filed abroad & 0.273 & $\mathbf{0 . 7 8 8}$ \\
\hline Applications for industrial designs to NPO & 0.990 & 0.072 \\
\hline Applications for industrial designs filed abroad & 0.281 & $\mathbf{0 . 7 5 7}$ \\
\hline GDP & 0.432 & $\mathbf{0 . 8 4 6}$ \\
\hline Science expenses & 0.340 & $\mathbf{0 . 8 9 9}$ \\
\hline MWE production & 0.809 & 0.400 \\
\hline Science funding by business & 0.414 & 0.870 \\
\hline Payments for IP & 0.111 & 0.575 \\
\hline Receipt from IP & -0.098 & 0.957 \\
\hline Number of observations & 40 & 40 \\
\hline
\end{tabular}

Calculated by the authors.

high-tech exports, and MWE production. The $R \& D$ expenses are related to the protection of IP abroad, receipts from IP, and GDP.

As it follows from Table 1, the number of IP objects should be associated with production and export of high-tech products. Indeed, applications for IP objects are in good correlation with the export of high-tech products (Table 2).

As for the relationship between science funding and the number of applications for inventions in the NPO, the correlation coefficient is not very high and is equal to 0.6. Even a weaker dependence of science funding (full funding from all sources) on the number of inventions in the NPO for a separate sample of countries is noted in (Arkhipova, Karpov, 2014). But IP protection abroad is highly correlated with GDP, R\&D expenses, and science funding by business.

Receipts from IP correlate with R\&D expenses (World Bank data of 2016, in dollars), the correlation coefficient is 0.86 .

Production of metalworking equipment (MWE) is associated with the export of hightech products and applications for all IP objects of residents to the NPO.
In addition to the above indicators, a correlation analysis was performed on patents for inventions obtained in 2016 by the residents in the NPO for information and communication technologies (according to $\mathrm{WIPO}^{1}$ ), these are technologies from number 2 to number 8 in the WIPO classification, and according to the number of researchers.

There is a strong correlation between the patents in the field of information and communications technology (ICT), the total number of applications to the NPO and applications filed abroad, the costs of R\&D, and receipt from IP (Table 4).

The number of research staff per 1 million people is highly correlated with R\&D funding as a share of GDP (with a correlation coefficient of $\mathbf{0 . 8 9}$ ). The absolute number of research staff correlates with other indicators of the «innovative potential of industry» (Table 5).

This study confirms the inextricable link between indicators of innovative development, namely, the export of high-tech products, IP and industrial production of metalworking equipment.

IP data also correlate with value added in industry (Fig. 1 and 2.) 
Table 4. Correlation coefficients between patents in the field of ICT, R\&D funding and receipts from IP

\begin{tabular}{|c|c|c|c|c|c|c|c|c|c|c|c|}
\hline & 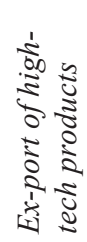 & 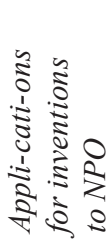 & 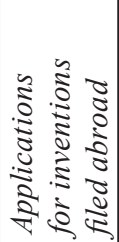 & 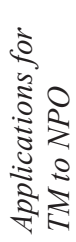 & 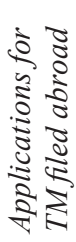 & 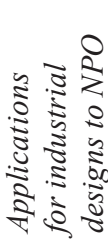 & 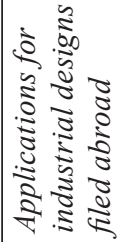 & 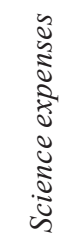 & 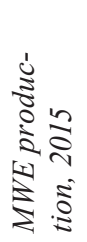 & 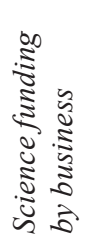 & 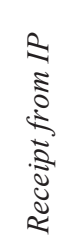 \\
\hline $\begin{array}{c}\text { ICT } \\
\text { patents }\end{array}$ & 0.68 & 0.75 & 0.83 & 0.58 & 0.55 & 0.56 & 0.54 & 0.94 & 0.68 & 0.97 & 0.74 \\
\hline
\end{tabular}

Calculated by the authors based on the data of the World Bank, WIPO, UNESCO, and Gardner Business Media.

Table 5. Correlation coefficients between the number of research staff and indicators on IP, high-tech export and MWE production in 2016

\begin{tabular}{|c|c|c|c|c|c|c|c|}
\hline & $\begin{array}{c}\text { Export of } \\
\text { high-tech } \\
\text { products }\end{array}$ & $\begin{array}{c}\text { Number of } \\
\text { applications } \\
\text { for inventions } \\
\text { to NPO }\end{array}$ & $\begin{array}{c}\text { Number of } \\
\text { applica- } \\
\text { tions for } \\
\text { TM to NPO }\end{array}$ & $\begin{array}{c}\text { Number of ap- } \\
\text { plications for } \\
\text { industrial de- } \\
\text { signs to NPO }\end{array}$ & $\begin{array}{c}\text { Science } \\
\text { expenses }\end{array}$ & $\begin{array}{c}\text { MWE } \\
\text { production }\end{array}$ & ICT patents \\
\hline $\begin{array}{c}\text { Research } \\
\text { staff }\end{array}$ & $\mathbf{0 . 8 3}$ & $\mathbf{0 . 8 7}$ & $\mathbf{0 . 7 6}$ & $\mathbf{0 . 7 4}$ & $\mathbf{0 . 8 8}$ & $\mathbf{0 . 7 8}$ & $\mathbf{0 . 9 2}$ \\
\hline
\end{tabular}

Calculated by the authors based on data of the World Bank, WIPO, UNESCO and Gardner Business Media.

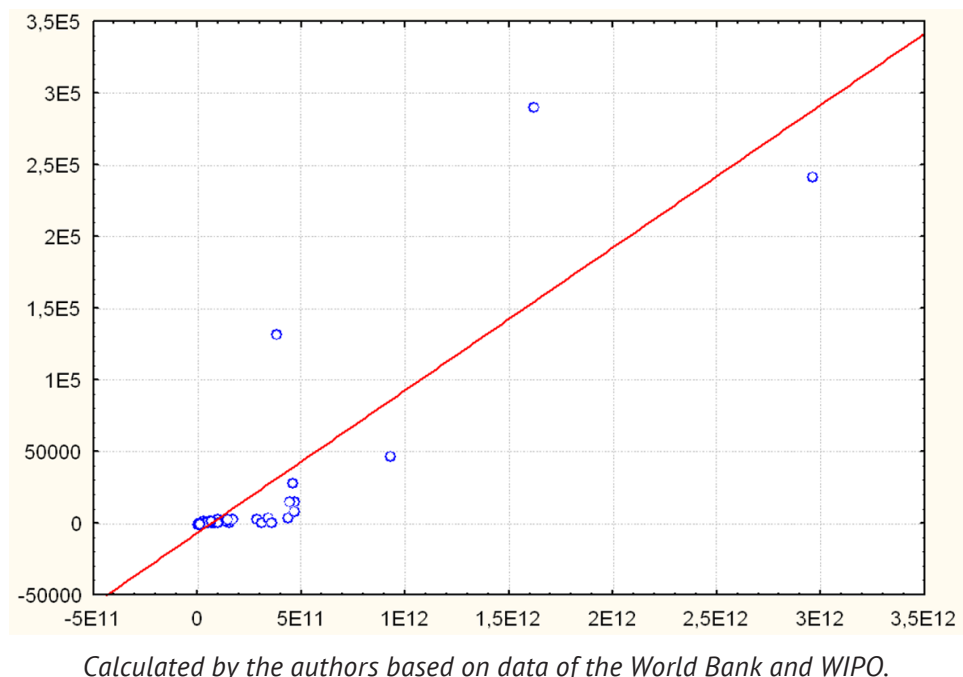

Fig. 1. Correlation between the value added in industry and applications of residents for inventions to the NPO in 2010

The correlation coefficient between the value added in industry and applications of residents for inventions to the NPO in 44 «innovatively advanced» countries that are at the top of the list by the share of high-tech export in 2010 is $\mathbf{0 . 8 6}$ (Fig. 1). The correlation coefficient for the value added in industry and resident' appli- cations for TM for all countries in 2010 is $\mathbf{0 . 9 1}$ (Fig. 2).

If we analyze which indicators are the cause, and which are the consequence, then it is obvious that the growth of industrial production causes an increase in applications for $T M$, industrial designs, and not vice versa. 


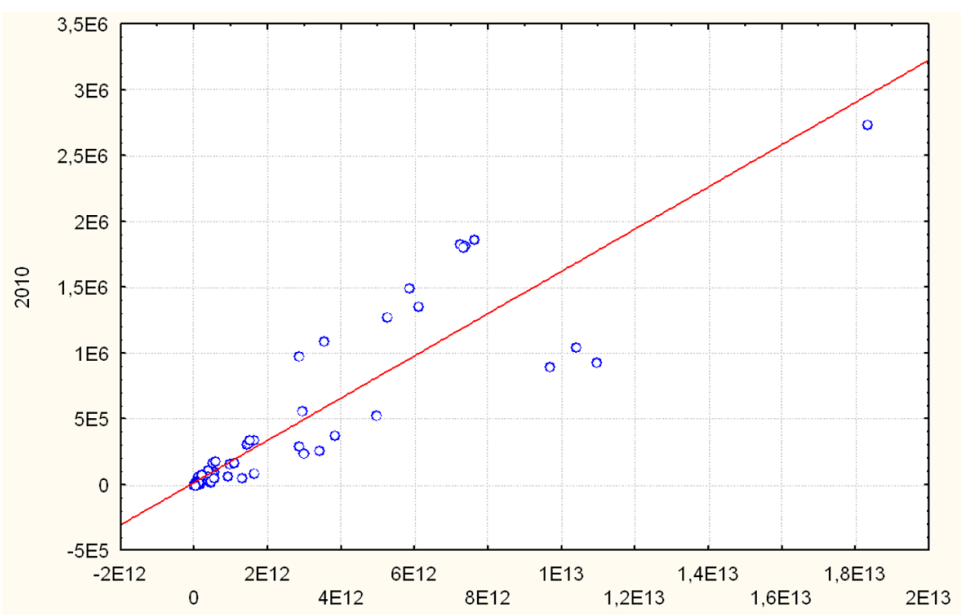

Calculated by the authors based on data of the World Bank and WIPO.

Fig. 2. Correlation between the value added in industry and applications of residents for trademarks to the NPO in 2010

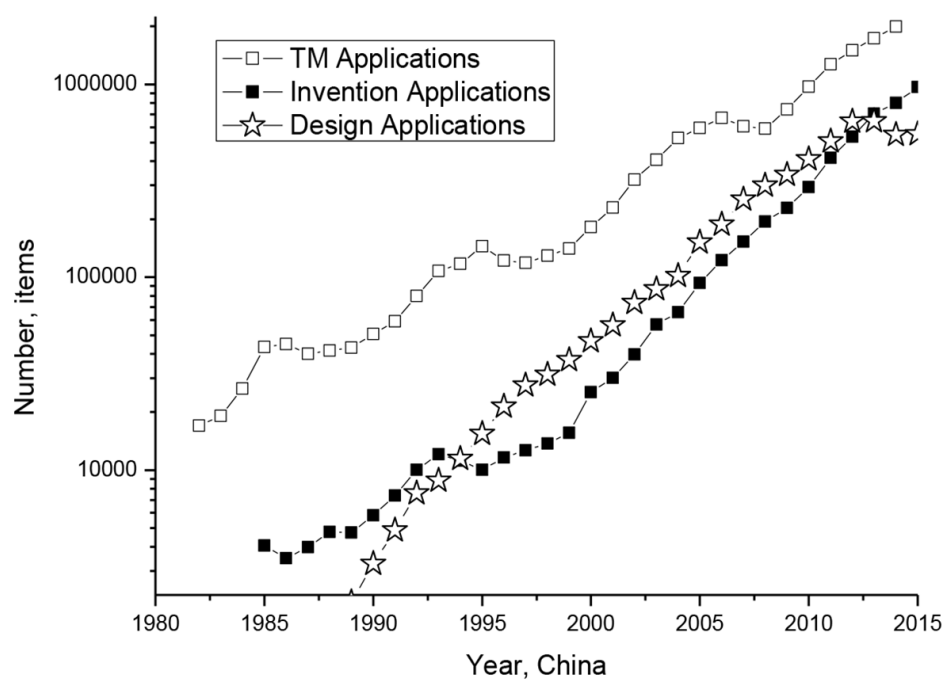

Fig. 3. Dynamics of protection of IP objects in China (residents to the NPO). According to WIPO - applications for TM; -applications for inventions; -applications for industrial designs Number, items / Year, China.

As for the relationship between inventions and industrial production, here the causal relation is not so obvious. What is primary? Whether the impact of innovation leads to an increase in industrial production (TM), or the developing industry (TM) stimulates science and innovation?

Let us consider the diagrams of TM and invention protection in the countries where the tran- sition to an innovative structure took place in a few decades: China, South Korea, and Japan (Fig. 3-5).

Using the example of China, it is easy to track that at the beginning of the innovation spurt, there is an increase in TM associated with the development of industry, which stimulates the financing of scientific research and the growth of applications for inventions and industrial designs (Fig. 3). 


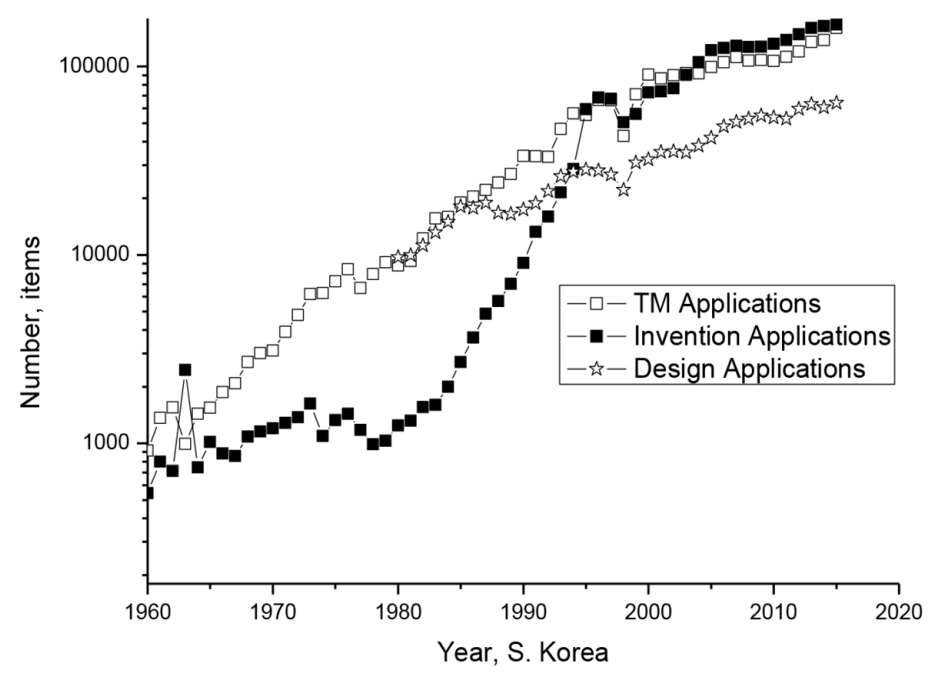

Fig. 4. Dynamics of protection of IP objects in South Korea (residents to the NPO). According to WIPO - Trademarks; - Inventions; - Industrial designs

Number, items / Year, S. Korea.

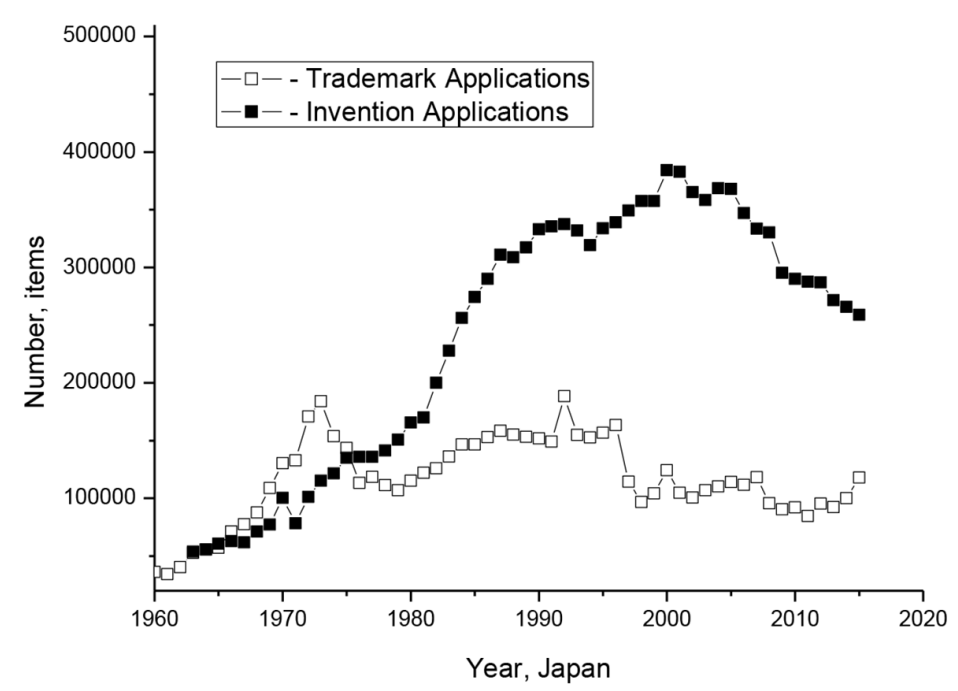

Fig. 5. Dynamics of protection of IP objects in Japan. According to WIPO

- Trademarks; - Inventions;

Number, items / Year, Japan.

In China, Japan and South Korea, this trend is repeated: at first there was an increase in TM, and then there was an increase in inventions (Fig. 3-5).

Thus, the dynamics of TM protection within the country and abroad can be an indicator of the development of industrial production. Accordingly, among the indicators on IP, the resident applications for TM are important because they are associated with the development of industry.

\section{Conclusions}

The relationship of IP indicators with indices characterizing the effectiveness of the national innovation system and the state of its 
subjects (science and industry) has been identified and statistically justified based on the correlation analysis of statistical data for 40 countries, selected by the share of high-tech products in export, taking into account the patterns of evolution of the characteristics of industrial property (IP) objects in the process of commercialization, in addition to the Global Innovation Indices and other systems for measuring innovative potential.

Export of high-tech products is an indicator of NIS performance and is in a fairly strong correlation with the number of resident applications for inventions, trademarks and industrial designs.

In this work, the data on production and export of metalworking equipment are examined as the state indicators for the high-tech industry. A strong correlation between the MWE production, high-tech exports, and IP data was found.

To assess the innovative potential of industry, it is proposed to take into account the indicator associated with production and export of metalworking equipment.

Two factors were identified using a statistical analysis. The first is related to indus- try and can be called «innovative industrial potential»: export of high-tech products, resident applications for inventions, TM, industrial designs to the National Patent Offices, and production of metalworking equipment. The second is related to GDP, IP protection abroad, science funding, and receipts from IP. It can be conditionally attributed to the scientific business: the productive power of science. The number of research staff also correlates with these indicators.

This study confirms the inextricable link between the indicators of innovative development, namely, the state of science and industry, including R\&D funding, export of high-tech products, IP and MWE production.

Thus, the data on IP objects can be indicators of the innovative level of industry: these are the data on inventions, TM, and industrial designs in the NPO, which, along with hightech export and MWE production, characterize the «innovative potential of industry». The productive power of science is associated with R\&D expenses, IP protection abroad, and receipts from IP.

\section{References}

Acs, Z., Audretsch, D.B. (1989). Patents as a Measure of Innovative Activities. In Kyklos, 42, $171-181$.

Arkhipova, M. Yu., Karpov, E.S. (2014). Statistical Analysis and Forecasting of Indicators of Patent Activity in Russia and A Number of Developed Countries. In Voprosy Statistiki, 6, 66-71.

Belousova, E.A. (2016). Financing and Efficiency of Research and Development in the Countries of European Union. In Economic Sciences. World Economy, 1(134), 163-169.

Chulok, A.A. (2006). Intellectual Property Rights Protection in Russia and Abroad: Measurement Problems and International Comparisons. In Russian Management Journal, 4 (2), 49-70.

Crescenzi, R., Rodríguez-Pose, A., Storper, M. (2007). The Territorial Dynamics of Innovation: a Europe-United States Comparative Analysis. In Journal of Economic Geography, 7 (6), 673-709.

Etzkowitz, H. (2008). The Triple Helix: University-Industry-Government Innovation in Action. Routledge, $180 \mathrm{p}$.

European Commission. Commission Staff Working Document (2007). Accompanying the Green Paper 'The European Research Area: New Perspectives' COM, 161, Brussels.

European Commission. Towards a European Research Area: Science, Technology and Innovation, Key Figures (2005). Luxembourg, Office for Official Publications of the European Communities.

Fagerberg, J., Feldman, M., Srholec, M. (2011). Technological Dynamics and Social Capability: Comparing U.S. States and European Nations. Paper no. 2011/11. Centre for Innovation, Research and Competence in the Learning Economy (CIRCLE), Lund University P. O. Available at: http://www.circle.lu.se/ publications. ISSN1654-3149.

Granstrand, O. (2004). The Economics and Management of Technology Trade: towards a Pro-Licensing Era? In Int. J. Technology Management, 27 (2/3), 209-240. 
Griliches, Z. (1990). Patent Statistics as Economic Indicators: A Survey. In Journal of Economic Literature, XXYIII, 1661-1707.

Heinrich A. (2001). The Recent History of The Machine Tool Industry and The Effects of Technological Change. 2001-14. University of Munich, Institute for Innovation Research and Technology Management.

Leydesdorff, L. (2005). The Triple Helix Model and the Study of Knowledge-based Innovation Systems. University of Amsterdam. Available at: https://arxiv.org/ftp/arxiv/papers/0911/0911.4291.pdf

Perepechko, L.N. (2014). Machine Tool Industry, Intellectual Property, and Gross Domestic Product. In Journal of World Economic Research, 3 (3), 21-24.

Smith, K. (2004). Measuring Innovation. In Fagerberg, J., Mowery. D. and R. R. Nelson (eds), The Oxford Handbook of Innovation, Oxford, Oxford University Press.

The Global Innovation Index: Stronger Innovation Linkages for Global Growth (2012). Soumitra Dutta, INSEAD - Editor, WIPO.

WIPO website. Available at: https://www.wipo.int/edocs/pubdocs/en/wipo_pub_958_3.pdf

Yagolnitser, M., Perepetchko, L. (2017). Innovative Development and Economic Growth. In Journal of Advanced Research in Law and Economics, 8 (1), 261-266. 